3 Fine MJ, Auble TE, Yealy DM, Hanusa BH, Weissfeld LA, Singer DE, et al A prediction rule to identify low-risk patients with community-acquired pneumonia. N Engl J Med 1997;336:243-50.

4 Schouten JA, Prins JM, Bonten MJ, Degener J, Janknegt RE, Hollander JMR, et al. Revised SWAB guidelines for antimicrobial therapy of community-acquired pneumonia. Neth J Med 2005;63:323-35

5 El Moussaoui R, Opmeer BC, Bossuyt PM, Speelman P, de Borgie CA Prins JM. Development and validation of a short questionnaire in community acquired pneumonia. Thorax 2004;59:591-5.

6 Chow AW, Hall CB, Klein JO, Kammer RB, Meyer RD, Remington JS Evaluation of new anti-infective drugs for the treatment of respiratory tract infections. Infectious Diseases Society of America and the Food and Drug Administration. Clin Infect Dis 1992;15(suppl 1):S62-88.

7 Drug Administration. Clin Infect Dis 1992;15(suppl 1):S62-88. Dunbar LM, Wunderink RG, Habib MP, Smith LG, Tennenberg AM,
Khashab MM, et al. High-dose, short-course levofloxacin for communityKhashab MM, et al. High-dose, short-course levofloxacin for communityacquired $\mathrm{P}$

8 Finch R, Schurmann D, Collins O, Kubin R, McGivern J, Bobbaers H, et al. Randomized controlled trial of sequential intravenous (i.v.) and oral moxifloxacin compared with sequential i.v. and oral co-amoxiclav with or without clarithromycin in patients with community-acquired pneumonia requiring initial parenteral treatment. Antimicrob Agents Chemother 2002;46:1746-54
9 Hagberg L, Torres A, van Rensburg D, Leroy B, Rangaraju M, Ruuth F Efficacy and tolerability of once-daily telithromycin compared with high-dose amoxicillin for treatment of community-acquired pneumonia. Infection 2002;30:378-86.

10 Ortiz-Ruiz G, Caballero-Lopez J, Friedland IR, Woods GL, Carides A. A study evaluating the efficacy, safety, and tolerability of ertapenem versus ceftriaxone for the treatment of community-acquired pneumonia in adults. Clin Infect Dis 2002;34:1076-83.

11 Petitpretz P, Arvis P, Marel M, Moita J, Urueta J. Oral moxifloxacin vs high-dosage amoxicillin in the treatment of mild-to-moderate, community-acquired, suspected pneumococcal pneumonia in adults. Chest 2001;119:185-95.

12 Vetter N, Cambronero-Hernandez E, Rohlf J, Simon S, Carides A, Oliveria T, et al. A prospective, randomized, double-blind multicenter comparison of parenteral ertapenem and ceftriaxone for the treatment of hospitalized adults with community-acquired pneumonia. Clin Ther of hospitalized ad
2002;24:1770-85.

13 Felmingham D, Gruneberg RN. The Alexander project 1996-1997: latest susceptibility data from this international study of bacterial pathogens from community-acquired lower respiratory tract infections. J Antimicrob Chemother 2000;45:191-203.

(Accepted 16 March 2006)

\title{
Commentary: What is the optimal duration of antibiotic therapy?
}

John Paul

Microbiology

Department, Royal

Sussex County

Hospital, Brighton

BN2 5BE

John Paul

consultant

tetrix@pavilion.co.uk
For some infections, such as Staphylococcus aureus bacteraemia or enterococcal endocarditis, clear evidence favours prolonged treatment to prevent relapse. Conversely, for some situations such as surgical prophylaxis and the treatment of gonorrhoea and of uncomplicated urinary tract infections in women, roles for short courses of antibiotics are well established. In this issue, El Moussaoui et al present evidence in favour of a total of three days' treatment for uncomplicated cases of community acquired pneumonia. ${ }^{1}$ This suggests that current guidelines recommending 7-10 days should be revised. ${ }^{2}$ In fact, the lack of evidence to support short course therapy for many common infections is surprising, and it has become accepted practice to continue treatment for days after symptoms have improved.

How can we improve our knowledge? This is an important question: antibiotics may be associated with adverse reactions, and prolonged exposure to antibiotics may encourage the development or acquisition of antibiotic resistant organisms. Also, antibiotic treatment is expensive and problems may occur with compliance. Comparative outcome studies provide a solution but require large numbers to provide the statistical power for significance. Pooling of multiple studies may be affected by inconsistencies in study design but may still yield clues-for example, a recent meta-analysis showed a five day course of cephalosporin to be superior to 10 days of penicillin for streptococcal pharyngitis. ${ }^{3}$ However, as a secure evidence base for clinical decision making, prospective multicentre trials probably provide the most definitive results.

El Moussaoui et al compared outcomes for cases of mild to moderate-severe community acquired pneumonia after treatment with antibiotics for three or eight days. ${ }^{1}$ The study involved nine hospitals in the Netherlands and was carried out as a randomised, double blind, placebo controlled non-inferiority trial. Patients who met entry criteria were treated with intravenous amoxicillin. Those who showed significant improvement after 72 hours were switched to either oral amoxicillin or placebo for five days. Clinical and radiological outcomes assessed at days 10 and 28 were not significantly different.

Not only does the study yield strong evidence in favour of short course therapy for a subset of patients with community acquired pneumonia, but also shows how centres can cooperate to tackle longstanding areas of uncertainty in clinical microbiology and infectious diseases. Many other common clinical situations would repay the efforts of comparable approaches. An example would be the treatment of vascular catheter related $S$ aureus bacteraemia. ${ }^{4}$ The literature suggests a minimum treatment period of 10-14 days, but some clinicians argue from experience that shorter periods are adequate: it would be good to know what the minimum treatment period should be, especially for methicillin resistant staphylococci and in patients whose long term prognosis is poor.

When optimising therapy for an infection, a lot of variables have to be juggled, including choice of antibiotic, the patient's immune status, the infecting agent, and the nature of the septic focus. Despite such difficulties, El Moussaoui et al show that by careful selection of case definition and comparison of standardised regimens it is possible to make medicine into more of a science.

\section{Competing interests: None declared.}

Fl Moussaoui R, de Borgie CAJM, van den Broek P Hustinx WN, Bresser $\mathrm{P}$, van den Berk GEL, et al. Effectiveness of discontinuing antibiotic treatment after three days versus eight days in mild to moderate-severe community acquired pneumonia: randomised, double blind study. $B M$ J 2006;332:1355-8.

2 British Thoracic Society Standards of Care Committee. BTS guidelines for the management of community acquired pneumonia in adults. Thorax 2001;56(suppl IV):1-64.

3 Casey JR, Pichichero ME. Meta-analysis of short course antibiotic treatment for Group A streptococcal tonsillopharyngitis. Paediatr Infect Dis J 2005;24:909-17

4 Fowler VG Jr, Sanders LL, Sexton DJ, Kong L, Marr KA, Gopal AK, et al. Outcome of Staphylococcus aureus bacteremia according to compliance with recommendations of infectious diseases specialists: experience with 244 patients. Clin Infect Dis 1998;27:478-86.

(Accepted 19 May 2006) 